\title{
INFORMASI AKUNTANSI, INFORMASI NON-AKUNTANSI, DAN KEPUTUSAN PEMBERIAN KREDIT
}

\author{
Mariana, Nadiarsyah, Syukriy Abdullah \\ Program Studi Akuntansi, Fakultas Ekonomi dan Bisnis, Universitas Syiah Kuala \\ Jl. Teuku Nyak Arief, Darussalam, Syiah Kula. Kota Banda Aceh, Aceh, Indonesia \\ *Email Koresponden: sykriyabdullah@unsyiah.ac.id
}

\begin{abstract}
This study aims to examine the effect of accounting information and non-accounting information on lending decisions on banking institutions in Pidie Jaya Regency, which amounted to 6 (six) banks for the period January 2014-February 2015. The data analyzed were debtor data using multiple linear regression. The results show that return on net worth, debt to equity ratio, and non-accounting information have a significant effect, while fixed assets turn over does not affect the lending decision in Pidie Jaya Regency. The limitation of this study is that the time span is not too long. In addition, this study does not explain further what if the sample used is a banking institution that applies sharia principles, which is most likely related to the characteristics of the community / customer in Aceh which generally applies Islamic Sharia.
\end{abstract}

Keywords: credit decision, fixed assets turn over, return on net worth, debt to equity ratio, information

\section{PENDAHULUAN}

Keputusan pemberian kredit merupakan hal penting bagi lembaga keuangan bank karena berkaitan dengan risiko kerugian dan sustainabilitas lembaga. Bank sebagai badan usaha menghimpun dana dari masyarakat dalam bentuk simpanan dan menyalurkannya kepada masyarakat dalam bentuk kredit dan/atau bentukbentuk lainnya, berfungsi sebagai intermediaries dalam perekonomian, untuk tujuan memperoleh laba. Oleh karena itu, pemberian kredit merupakan kegiatan bank yang paling penting. Bank menerima dana/simpanan dari pihak lain dan kemudian meminjamkan dana kepada pihak lain dengan mendapatkan kompensasi berupa bunga, sehingga bank sering dianggap berdagang uang dalam bentuk hutang (Zremag, 2016). Namun, pemberian kredit memiliki risiko, sehingga harus dilakukan secara hati-hati.

Penyaluran kredit dilakukan dalam bentuk kredit modal kerja, kredit investasi, dan kredit golongan berpenghasilan tetap (GBT), baik konsumtif ataupun investasi. Aktivitas penyaluran kredit merupakan suatu kegiatan utama yang memberikan pendapatan lebih besar kepada bank jika dibandingkan layanan jasa (feebased income). Hal ini berbeda dengan negara maju yang mana layanan jasa justru lebih signifikan, dimana inovasi pelayanan jasa sudah sangat luas, seperti kartu kredit, automatic teller machine (ATM), automatic grab fund (AGF), automatic fund transfer (AFT), serta pelayanan pembayaran tagihan listrik (PLN), telepon (Telkom), air (PDAM), dan sebagainya.

Proses pengambilan keputusan pemberian kredit merupakan hal sangat penting bagi bank. Bank akan melakukan analisis atas kelayakan setiap pemohon kredit secara cermat dengan menggunakan berbagai informasi yang tersedia sebelum memutuskan menyetujui atau menolak suatu permohonan kredit. Jika bank menyetujuinya, maka calon debitur akan memperoleh offering letter atau surat persetujuan prinsip bersyarat dari bank. Perjanjian dan pemufakatan kredit, biasa-

\section{7}

Diterima:

10 Oktober 2018

Direvisi:

25 Oktober 2018

Disetujui:

29 Oktober 2018

Artikel ini tersedia di website: http:// ejournal.umm.ac.id/ index.php/jrak

Doi: $10.22219 /$ jrak.v8i2.37

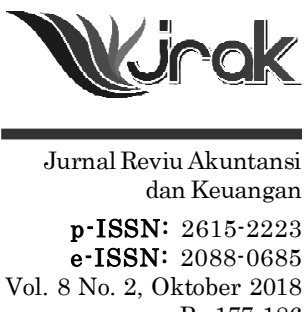


Penggunaan

Rasio

Keuangan... nya dituangkan dalam surat perjanjian kredit antara pemberi dan penerima kredit (Syahputra, 2009:70).

Informasi akuntansi dan non akuntansi sangat penting untuk pengambilan keputusan kredit (Saleh, et al., 2014). Informasi akuntansi merupakan informasi yang tertuju pada kondisi finansial yang dapat diperoleh laporan keuangan debitur, seperti fixed asset turn over (FATO), return on net worth (RONW) dan debt to equity ratio (DER) (Ustadi, 1993; Suroso, 2003; Septriawan, 2010; Karo-karo, 2011; dan Matondang, 2011). Informasi non akuntansi merujuk kepada pribadi atau pihak-pihak yang pernah terkait dengan aktivitas bisnis calon debitur. Menurut Septriawan (2010), informasi non akuntansi dapat diperoleh secara kualitatif melalui proses penilaian terhadap kualitas manajemen calon debitur tentang strategi pemasaran, rencana jangka pendek dan jangka panjang bisnis mereka.

Beberapa penelitian terdahulu telah menganalisis pengaruh informasi akuntansi dan informasi non akuntansi terhadap keputusan pemberian kredit. Studi yang dilakukan oleh Sudaryono (2005), Matondang (2011), dan Agusthia (2012) menemukan bahwa kedua jenis informasi tersebut digunakan dalam proses pengambilan keputusan kredit. Temuan Mintarti (1994) dan Suroso (2003) menyatakan bahwa informasi akuntansi berpengaruh terhadap pengambilan keputusan kredit. Lebih rinci, pengaruh RONW terhadap proses pengambilan keputusan kredit ditemukan oleh Ustadi (1993), Septriawan (2010), dan Matondang (2011), sementara pengaruh DER dibuktikan oleh Suroso (2003) dan Septriawan (2010). Namun, Ustadi (1993) dan Matondang (2011) tidak dapat menunjukkan adanya pengaruh FATO terhadap keputusan pemberian kredit. Niode, et al. (2016) menemukan bahwa informasi non akuntansi berpengaruh terhadap keputusan pemberian kredit, namun informasi akuntansi tidak berpengaruh. Sementera Hasibuan (2003) tidak menemukan pengaruh informasi akuntansi dan non akuntansi terhadap keputusan kredit.

Adanya perbedaan hasil dan temuan pada penelitian terdahulu mendorong dilakukannya penelitian ini, dengan menggunakan lokasi dan data berbeda, yakni dengan menggunakan data perbankan di Kabupaten Pidie Jaya, Aceh. Data seluruh permohonan kredit selama Januari 2014-Februari 2015 ada sebanyak 3.593 calon debitur, yang diterima 3.336 debitur dan yang ditolak 256 calon debitur. Persyaratan untuk pengajuan kredit sudah ditetapkan dan dipenuhi oleh calon debitur, seperti adanya usaha debitur yang dilengkapi dengan laporan keuangan, SIUP, SITU, dan surat keterangan usaha dari kepala desa, pas foto suami istri dan jika belum berkeluarga maka wajib ada ahli waris, fotokopi kartu keluarga, dana agunan (BPKB, sertifikat, atau akta).

\section{Pengaruh Fixed Asset Turn Over terhadap Keputusan Pemberian Kredit}

Pendapatan atau penjualan suatu perusahaan merupakan salah satu indikator keberhasilan dan keberlanjutan (sustainability) suatu perusahaan, terutama untuk jangka panjang. Kemampuan menghasilkan pendapatan sangat dipengaruhi oleh aset tetap perusahaan, khususnya aset tetap. Rasio ini mengukur seberapa efektif pemanfaatan aset tetap oleh perusahaan calon debitur. Aset tetap yang tidak dimanfaatkan dengan baik justru membebani operasional perusahaan karena adanya biaya pemeliharaan dan perawatan aset tetap bersangkutan.

Lembaga perbankan menggunakan rasio FATO ini untuk menilai seberapa besar kemampuan perusahaan debitur menghasilkan penjualan dari aset tetap yang dimilikinya. FATO merupakan perbandingan antara jumlah penjualan pada satu periode dengan jumlah aset tetap perusahaan, yang secara empiris menjadi rasio penting bagi analisis kredit dalam membuat keputusan kredit. Namun, hasil penelitian Ustadi (1993), Septriawan (2010), dan Matondang (2011) menunjukan bahwa FATO tidak berpengaruh terhadap keputusan pemberian kredit. Berdasarkan pemahaman ini, maka hipotesis tentang pengaruh FATO terhadap keputusan pemberian kredit dapat dinyatakan seperti berikut:

H1: FATO berpengaruh terhadap keputusan pemberian kredit. 
Analisis rasio RONW dapat digunakan untuk melihat peran ekuitas dalam menghasilkan keuntungan bagi pemodal/pemilik. Laba yang tinggi lebih baik bagi pemilik. Pada usaha kecil dan mikro, semakin tinggi laba bersih maka semakin baik arus kas yang dihasilkan. Meningkatnya laba bersih berimplikasi pada peningkatan ekuitas dan kesejahteraan pemilik melalui peningkatan aset perusahaan. Bagi bank, sebagai pihak pemberi pinjaman, peningkatan rasio laba terhadap ekuitas menunjukkan prospek yang bagus dari perusahaan calon debitur.

Penelitian yang dilakukan Ustadi (1993) dan Matondang (2011) menemukan bahwa RONW berpengaruh terhadap proses pengambilan keputusan kredit, sedangkan Septriawan (2010) dan Suroso (2013) tidak menemukan adanya pengaruh RONW terhadap keputusan pemberian kredit. Adanya keterkaitan RONW dengan keputusan pemberian kredit dapat dipertegas dengan pernyataan hipotesis kedua sebagai berikut:

H2: RONW berpengaruh terhadap keputusan pemberian kredit.

\section{Pengaruh Debt to Equity Ratio (DER) terhadap Keputusan Pemberian Kredit}

DER perbandingan antara hutang lancar dan hutang jangka panjang dengan jumlah modal sendiri. DER digunakan untuk melihat kondisi leverage, yaitu berapa besar modal sendiri yang dimiliki calon debitur untuk mendukung operasional perusahaan, apakah kondisi leverage masih berada pada tingkat yang wajar atau telah berada pada posisi yang mengkhawatirkan. Menurut Suroso (2003) semakin tinggi rasio perbandingan antara total hutang yang ada dengan total ekuitas yang ada semakin tinggi tingkat leverage suatu unit usaha.

DER atau leverage yang tinggi menunjukkan tingginya suatu usaha yang didanai yang bersumber dari hutang. Semakin tinggi hutang yang ada menyebabkan semakin sulitnya suatu usaha untuk melunasi kewajiban dengan asumsi cash flows yang terbatas. DER berpengaruh terhadap keputusan pemberian kredit (Suroso, 2003; Septriawan, 2010; Nurdiwaty dan Faisol, 2017). Apabila DER rendah maka semakin besar kemungkinan permohonan kredit untuk dikabulkan. Sementara penelitian Tjondro dan Basuki (2012) menemukan hasil sebaliknya, yaitu financial leverage tidak mempengaruhi penilaian dalam keputusan pemberian kredit bank. Hipotesis ketiga dinyatakan seperti berikut:

H3: DER berpengaruh terhadap Keputusan Pemberian Kredit

\section{Pengaruh Informasi Non Akuntansi terhadap Keputusan Pemberian Kredit}

Informasi non akuntansi yang berupa agunan/jaminan. Jaminan kredit diartikan sebagai penyerahan kekayaan atau pernyataan kesanggupan seseorang untuk menanggung pembayaran kembali suatu utang. Jaminan kredit berupa jaminan perorangan dan jaminan kebendaan. Barang yang dapat dijamin di dalam jaminan kebendaan berupa barang bergerak dan barang tidak bergerak. Menurut Mahrinasari (2003), nilai jaminan dapat mempengaruhi keputusan pemberian fasilitas kredit. Jalan terakhir penyelesaian kredit harus melalui pencairan jaminan apabila kredit tidak dapat dilunasi. Selain itu Ustadi (1993), berpendapat bahwa semakin tinggi nilai jaminan maka semakin baik untuk kemungkinan memperoleh kredit. Hubungan antara informasi non akuntansi dengan keputusan kredit adalah positif.

Penilaian informasi non akuntansi dilakukan dengan menghitung pembagian antara plafon pinjaman dengan nilai anggunan. Penelitian yang dilakukan Septriawan (2010), Sucipto (2011), Matondang (2011), dan Jacob, et al. (2014) menemukan bahwa informasi non akuntansi berpengaruh terhadap keputusan pengambilan keputusan kredit. Sejalan dengan pemahaman ini, maka hipotesis keempat dapat dinyatakan seperti berikut: 
Penggunaan Rasio

Keuangan...

180
H4: Informasi Non Akuntansi berpengaruh terhadap keputusan pemberian kredit.

\section{METODE PENELITIAN}

\section{Populasi dan Sampel}

Populasi dalam penelitian ini yaitu seluruh perbankan yang beroperasi di Kabupaten Pidie Jaya dengan unit analisis debitur perbankan yang terhitung sejak Januari 2014 sampai dengan Februari 2015. Dari 3.336 debitur, dipilih sebanyak 500 debitur sebagai sampel yang diperoleh dari 6 bank yang ada di wilayah Kabupaten Pidie Jaya, Aceh.

\section{Operasionalisasi Variabel}

Variabel dalam penelitian ini terdiri dari variabel dependen yaitu keputusan pemberian kredit (KPK), sedangkan variabel independennya adalah informasi akuntansi (FATO, RONW dan DER) dan informasi non akuntansi. Definisi operasional dan pengukuran untuk masing-masing variabel dalam penelitian ini adalah:

1. Keputusan pemberian kredit (KPK) adalah jumlah permohonan kredit yang disetujui oleh pihak bank. variabel ini diukur dengan menggunakan ketetapan repayment capacity (RPC) atau kemampuan membayar yang telah ditetapkan oleh perbankan. Semakin tinggi nilai RPC, maka semakin besar peluang pemberian kredit.

2. Fixed Assets Turn-Over (FATO) adalah kemampuan debitur menghasilkan pendapatan dari aset tetap yang dimilikinya. Semakin tinggi nilai FATO, maka peluang diberikan kredit akan semakin besar. Variabel ini diukur dengan rasio penjualan terhadap total aset tetap bersih.

3. Return on Net Worth (RONW) mencerminkan kemampuan perusahaan menghasilkan laba bersih dengan menggunakan kekayaan bersih atau modal sendiri. Nilai RONW yang semakin besar dipandang oleh bank memiliki prospek yang lebih baik. Pengukuran variabel ini menggunakan angka rasio laba bersih terhadap ekuitas.

4. Debt to Equity Ratio (DER) menunjukkan risiko keuangan perusahaan karena menggunakan hutang sebagai sumber pendanaannya. Semakin tinggi nilai rasio ini bagi bank dianggap semakin berisiko untuk diberi pinjaman. Pengukuran variabel ini menggunakan angka rasio total hutang terhadap total ekuitas.

5. Informasi Non Akuntansi (INA) adalah informasi terkait agunan yang merupakan jaminan tambahan yang diserahkan debitur kepada bank dalam rangka pemberian fasilitas kredit atau pembiayaan. Bagi bank, informasi ini penting untuk memastikan bahwa bila terjadi kemacetan, maka bank tidak mengalami kerugian karena dapat mengkonversi jaminan atau agunan menjadi kas sebagai pengganti dana pinjaman dan bunga yang belum dikembalikan. Pengukuran variabel ini menggunakan rasio plafon pinjaman terhadap nilai agunan.

\section{Metode Analisis Data}

Penelitian ini menggunakan regresi linier berganda (multiple regression) untuk memprediksi pengaruh variabel independen, yang terdiri dari fixed asset turn over (FATO), return on net worth (RONW), rebt to equity ratio (DER), dan INA (informasi non akuntansi) terhadap variabel dependen (Y), yakni Keputusan Pemberian Kredit (KPK). Penarikan kesimpulan didasarkan pada nilai signifikansi $(\alpha)$ sebesar $5 \%$, baik untuk model maupun untuk pengaruh masing-masing variabel bebas. 


\section{Hasil Regresi Linier Berganda}

Pengujian hipotesis dilakukan dengan analisis regresi linear berganda. Hasil regresi linear berganda disajikan dalam Tabel 1 berikut.

\begin{tabular}{lcccc}
\hline \multicolumn{1}{c}{ Variabel } & Koefisien & Std. Error & Nilai t & Nilai Sig. \\
\hline Constant & 0,735 & 0,005 & 144,111 & 0,000 \\
Fixed assets turn over (FATO) & $-0,012$ & 0,007 & $-1,738$ & 0,083 \\
Return on net worth (RONW) & $-0,218$ & 0,025 & $-8,756$ & 0,000 \\
Debt to equity ratio (DER) & 0,001 & 0,001 & 2,340 & 0,020 \\
Informasi non akuntansi (INA) & 0,011 & 0,004 & 2,554 & 0,011 \\
Nilai F = 22,367 & Sig = $=0,000$ & & & \\
$\mathrm{R}=0,391$ & $\mathrm{R}^{2}=0,153$ & \multicolumn{3}{c}{ Adj. $\mathrm{R}^{2}=0,146$} \\
\hline
\end{tabular}

Berdasarkan ringkasan hasil pengolahan data pada Tabel 1 dapat dibangun persamaan regresi seperti berikut:

$\mathrm{KPK}=0,735-0,012 \mathrm{FATO}-0,218 \mathrm{RONW}+0,001 \mathrm{DER}+0,011 \mathrm{INA}+\mathrm{e}$.

Nilai $\mathrm{F}$ value untuk persamaan regresi tersebut adalah sebesar 22,367 dengan nilai signifikansi sebesar 0,000. Kedua angka ini memiliki makna bahwa variabel independen secara bersama-sama (dalam sebuah model atau persamaan) berpengaruh signifikan terhadap variabel dependen. Nilai signifikansi yang lebih kecil dari 0,05 menunjukkan bahwa model penelitian yang dibangun dengan menggunakan empat variabel independen ini dapat digunakan untuk memprediksi keputusan pemberian kredit oleh bank. Artinya, variabel FATO, RONW, DER, dan INA adalah prediktor untuk keputusan pemberian kredit pada perbankan di Kabupaten Pidie Jaya. Arti nilai koefisien determinasi $\left(\mathrm{R}^{2}\right)$ sebesar $15,3 \%$ adalah kemampuan semua variabel independen dalam menjelaskan perubahan KPK relatif kecil karena persentase yang lebih besar, yakni 84,7\%, dijelaskan oleh variabel lain yang tidak dimasukan dalam model penelitian ini.

\section{Pengaruh Fixed Assets Turn Over (FATO) terhadap Keputusan Pemberian Kredit}

Hasil penelitian pada Tabel 1 (lihat baris ketiga) menunjukan nilai signifikansi (Sig.) untuk variabel FATO sebesar 0,083 (lebih besar dari derajat signifikansi $5 \%$ atau 0,05 ) dengan nilai t $-1,738$ (bertanda negatif). Berdasarkan hasil ini dapat dinyatakan bahwa hipotesis yang menyatakan FATO berpengaruh terhadap KPK ditolak. Artinya, variabel FATO secara statistik tidak berpengaruh terhadap keputusan pemberian kredit pada perbankan di Kabupaten Pidie Jaya. Namun, besaran nilai koefisien variabel FATO sebesar -0,012, menunjukan adanya arah negarif, yang bermakna bahwa kenaikan nilai variabel FATO naik 1 (satu) persen akan berakibat pada turunnya peluang pemberian kredit sebesar 0,012 persen (dengan asumsi variabel lain konstan).

Hasil yang menyatakan bahwa FATO tidak berpengaruh secara signifikansi terhadap keputusan pemberian kredit pada perbankan di Kabupaten Pidie Jaya menunjukan adanya kecenderungan calon debitur yang mengajukan permohonan kredit adalah debitur yang baru dalam usahanya, bukan debitur dengan usaha yang telah beroperasi lama. Biasanya, usaha yang sudah berlangsung lama memiliki nilai aset yang berkorelasi kuat dengan tingkat pendapatannya. Hardinata
Tabel 1

Hasil Regresi

Linear Berganda 
Penggunaan

Rasio

Keuangan...

(2014) menemukan bahwa umur usaha berpengaruh negatif terhadap pemberian kredit.

Analisis FATO digunakan untuk melihat seberapa besar aktiva tetap dapat dimanfaatkan untuk menghasilkan pendapatan. Menurut Matondang (2011), variabel FATO akan berpengaruh terhadap keputusan pemberian kredit apabila perusahaan debitur telah berlangsung lama atau berusia tua. Suroso (2003) menyatakan bahwa jika semakin besar aktiva digunakan maka semakin besar pula laba yang diperoleh, sehingga semakin besar arus kas masuk. Artinya, besaran arus kas masuk secara regular sangat penting bagi analis kredit dalam pembuatan keputusan kredit.

Hasil penelitian ini mendukung hipotesis yang menyatakan bahwa FATO tidak berpengaruh terhadap keputusan pemberian kredit. Hasil ini konsisten dengan hasil penelitian Ustadi (2003), Septriawan (2010) dan Matondang (2011) menemukan bahwa variabel FATO tidak berpengaruh terhadap keputusan pemberian kredit.

\section{Pengaruh Return on Net Worth (RONW) terhadap Keputusan Pemberian Kredit}

Berdasarkan hasil regresi yang disajikan pada Tabel 1 (baris keempat) diketahui bahwa besaran nilai signifikansi RONW adalah 0,000 dengan nilai t sebesar -8,756. Tanda negatif menunjukan pengaruh variabel RONW yang negatif terhadap variabel KPK. Nilai Sig. sebesar 0,000 tersebut lebih kecil dari kriteria hipotesis, yakni $\alpha=5 \%$, yang berarti bahwa RONW berpengaruh negatif dan signifikansi terhadap keputusan pemberian kredit pada perbankan di Kabupaten Pidie Jaya. Nilai koefisien variabel RONW sebesar -0,218 menjelaskan bahwa jika RONW naik 1 (satu) persen, maka akan berakibat pada menurunnya keputusan pemberian kredit sebesar 0,218 persen, dengan asumsi variabel lain konstan.

RONW berpengaruh negatif terhadap keputusan pemberian kredit pada perbankan dapat dimaknai sebagai pertanda bahwa kemampuan perusahaan debitur dalam memperoleh laba menjadi pertimbangan penting bagi bank dalam pembuatan keputusan pemberian kredit. Rasio ini dikembangkan dari perspektif investor, bukan perspektif perusahaan. ${ }^{1}$ Menurut Matondang (2011), semakin tinggi laba bersih maka semakin baik cash flows yang dihasilkan dari aktivitas operasi, aktivitas pendanaan dan aktivitas investasi. Meningkatnya laba bersih menyebabkan meningkatnya kesejahteraan pemilik sehingga meningkatkan ekuitas pemilik yang nantinya memiliki kaitan dengan meningkatnya assets perusahaan.

Hasil penelitian ini tidak mendukung hipotesis yang menyatakan bahwa RONW berpengaruh terhadap keputusan pemberian kredit. Selanjutnya hasil penelitian ini konsisten dengan hasil penelitian yang dilakukan Septriawan (2010) dan Suroso (2013), yang menemukan bahwa RONW berpengaruh negatif dan signifikansi terhadap proses pengambilan keputusan kredit. Sementara penelitian lain menemukan hasil berbalik, seperti Ustadi (1993) dan Matondang (2011) yang menemukan bahwa RONW berpengaruh terhadap proses pengambilan keputusan kredit.

\section{Pengaruh Debt to Equity Ratio (DER) terhadap Keputusan Pemberian Kredit}

Berdasarkan hasil regresi pada Tabel 1 (lihta baris kelima) diketahui bahwa nilai koefisien, signifikansi, dan $t$ untuk variabel DER masing-masing adalah 0,001, 0,020, dan 2,340. Nilai Sig. sebesar 0,020 lebih kecil dari derajat signifikansi yang ditetapkan, yakni $\alpha=5 \%$, atau ditulis $0,02<0,05$. Hal ini bermakna bahwa hipotesis

\footnotetext{
${ }^{1} \mathrm{https}$ ///efinancemanagement.com/financial-analysis/return-on-net-worth
} 
alternatif ketiga yang menyatakan bahwa DER berpengaruh terhadap keputusan pemberian kredit tidak dapat ditolak, atau secara empiris terbukti untuk data perbankan di Kabupaten Pidie Jaya. Nilai koefisien regresi variabel DER sebesar 0,001 menunjukan bahwa jika DER naik 1 (satu) persen, akan berakibat pada naiknya keputusan pemberian kredit sebesar 0,001 persen (dengan asumsi variabel lain konstan).

DER berpengaruh positif dan secara statistik signifikansi terhadap keputusan pemberian kredit memiliki implikasi bahwa jumlah hutang berjalan yang dimiliki oleh sebuah perusahaan calon debitur adalah faktor yang menentukan bagi bank dalam memutuskan apakah memberikan kredit atau tidak. Bagi bank, semakin besar rasio ini akan semakin tidak menguntungkan karena semakin besar risiko yang ditanggung bank jika terjadi kegagalan bayar oleh debitur. Secara implisit, berdasarkan nilai DER dapat diketahui berapa nilai modal sendiri yang menjadi jaminan utang.

Menurut Matondang (2011) apabila DER rendah maka semakin besar kemungkinan permohonan kredit untuk dikabulkan. Nilai DER yang semakin menurun menunjukkan semakin membaiknya keadaan perusahaan, khususnya ketika terjadi peningkatan laba. Peningkatan laba adalah indikator perbaikan kinerja perusahaan debitur, sehingga berdampak pada kenaikan ekuitas (berupa laba ditahan) dan menurunkan nilai DER (dengan asumsi tidak terjadi kenaikan hutang selama tahun berjalan).

Hasil penelitian ini mendukung hipotesis yang menyatakan bahwa DER berpengaruh terhadap keputusan pemberian kredit. Hasil penelitian ini konsisten dengan hasil penelitian yang dilakukan Ustadi (1993), Septriawan (2010), Matondang (2011), Putranto dan Arfinto (2014), Nurdiwaty dan Faisol (2017) yang menemukan bahwa DER berpengaruh terhadap proses pengambilan keputusan kredit. Penelitian Blankespoor (2013) menemukan bahwa financial leverage mempengaruhi risiko kredit sehingga dapat dijadikan dasar keputusan pemberian kredit bank. Sementara penelitian Tjondro dan Basuki (2012) tidak menemukan adanya pengaruh financial leverage terhadap keputusan pemberian kredit bank.

\section{Pengaruh Informasi Non Akuntansi terhadap Keputusan Pemberian Kredit}

Berdasarkan hasil regresi pada Tabel 1 (lihat baris keenam) diketahui bahwa nilai signifikansi (Sig.) variabel informasi non akuntansi sebesar 0,011 dengan besaran nilai t sebesar 2,554 (positif). Nilai 0,011 tersebut lebih kecil dari $\alpha=5 \%$ atau 0,05sehingga dapat dinyatakan bahwa secara statistik variabel INA pengaruh positif signifikan terhadap variabel KPK. Artinya, semakin lengakp informasi INA, maka semakin baik keputusan pemberian kredit pada perbankan di Kabupaten Pidie Jaya. Nilai koefisien ini menjelaskan bahwa jika INA naik 1 (satu) persen, akan berakibat pada naiknya keputusan pemberian kredit sebesar 0,011 persen, dengan asumsi variabel lain konstan.

Hasil ini mendukung hipotesis yang dinyatakan sebelumnya bahwa INA berpengaruh terhadap keputusan pemberian kredit. Ketika INA diukur dengan menggunakan informasi agunan, maka besarnya nilai jaminan kredit dapat disimpulkan bahwa besaran agunan sangat penting bagi bank dalam memutuskan pemberian kredit. Secara teori, nilai agunan harus lebih besar dari nilai kredit yang diterima, karena jaminan kredit merupakan sumber dana untuk pelunasan kredit yang diberikan oleh bank apabila kredit yang dicairkan mengalami kegagalan. Untuk itu, bank harus menilai keabsahan kepemilikan aset debitur yang menjadi agunan untuk memperkecil resiko bank dalam penyaluran kredit.

Menurut Matondang (2011), Putranto dan Arfinto (2014), nilai jaminan dapat mempengaruhi keputusan pemberian fasilitas kredit. Dikarenakan saat terjadi macet jalan terakhir yang di ambil oleh pihak pemberi kredit dalam penyelesaian kredit melalui pencairan jaminan apabila. Selain itu Ustadi (1993), berpendapat bahwa semakin tinggi nilai jaminan maka semakin baik untuk kemungkinan memperoleh kredit. 
Penggunaan

Rasio

Keuangan...

184

Hasil penelitian ini mendukung hipotesis yang menyatakan bahwa informasi non akuntansi berpengaruh terhadap keputusan kredit. Hasil penelitian ini konsisten dengan temuan Suroso (2003), Septriawan (2010), Sucipto (2011), Matondang (2011), Jacob, et al., (2014) dan Niode, et al. (2016), namun ini berbalikan dengan temuan Purba (2017) yang menyatakan bahwa informasi akuntansi tidak berpengaruh terhadap keputusan pemberian kredit

\section{SIMPULAN}

Berdasarkan hasil analisis atas model regresi yang digunakan dapat simpulan bahwa FATO tidak berpengaruh terhadap keputusan pemberian kredit pada perbankan di Kabupaten Pidie Jaya. Akan tetapi, DER, RONW dan INA berpengaruh terhadap keputusan pemberian kredit pada lembaga perbankan di Kabupaten Pidie Jaya. Keterbatasan penelitian ini adalah rentang waktu yang tidak terlalu panjang. Selain itu, penelitian ini tidak menjelaskan lebih jauh bagaimana jika sampel yang digunakan adalah lembaga perbankan yang menerapkan prinsip-prinsip syariah, yang kemungkinan besar memiliki kaitan dengan karakteristik masyarakat/nasabah di Aceh yang secara umum menerapkan Syariat Islam. Perlu diketahui bahwa bank terbesar di Aceh saat ini adalah PT Bank Aceh Syariah.

Berdasarkan penelitian yang telah dilakukan, beberapa saran yang dapat diberikan adalah Informasi akuntansi berupa rasio return on net worth (RONW), debt to equity ratio (DER), dan informasi non akuntansi (INA) penting digunakan dalam proses pengambilan keputusan pemberian kredit, sehingga tidak dapat diabaikan oleh lembaga perbankan. Penelitian selanjutnya dapat menambah jumlah sampel dan rentang waktu penelitian yang lebih panjang. Memperluas cakupan bank yang diteliti dengan memasukkan bank Syariah. Bank Syariah lebih diminati di Aceh karena masyarakat dan pemerintahan daerah di Aceh saat ini menerapkan prinsip-prinsip Syariah dalam kehidupan sehari-hari.

\section{DAFTAR PUSTAKA}

Agusthia, H. 2012. Analisis Pengaruh Informasi Akuntansi dan Informasi Non Akuntansi terhadap Keputusan Kredit. Accounting Analysis Journal 1(2).

Argyris, C. 1952. The Impact of Budgets on People. Ithaca: School of Business and Public Administration, Cornell University.

Baskara, I Gde Kajeng, Ubud Salim, Djumahir, \& Atim Djazuli. 2017. The role of borrower characteristics, relationship lending and trust on SME's Creditworthiness. International Journal of Economic Research 14(3).

Belkaoui, A. 2001. Teori Akuntansi. Yogyakarta: AK Group.

Blankespoor, E., T.J. Linsmeier, K.R. Petroni, \& C. Shakespeare. 2013. Fair Value Accounting for Financial Instruments: Does It Improve the Association between Bank Leverage and Credit Risk? The Accounting Review 88(4).

Danos, Paul, Doris L. Holt, \& Eugene A. Imhoff, Jr. 1989. The Use of Accounting Information in Bank Lending Decisions. Accounting Organizations and Society $14(3)$.

Estenson, L. 1996. How a Banker Looks at Financial Leverage. Year in Cooperation: A Cooperative Development Magazine 2(2).

Firdaus, M. 2011. Ekonometrika: Suatu Pendekatan Aplikasi. Edisi 2. Jakarta: Bumi Aksara. 
Freeman, R.N., J.A.Ahlson, \& S.H. Penman. 1982. Book Rate of Return Prediction of Earning Changes: An Empirical Investigation. Journal of Accounting Research 20(2).

Ghozali, I. 2013. Aplikasi Analisi Multivariate dengan Program IBM SPSS 21. Semarang: Universitas Dipenogoro.

Harahap, S.S. 2007. Teori Akuntansi. Jakarta: Penerbit Raja Grafindo Persada.

Hardinata, Y. 2014. Analisis Keputusan Pemberian Kredit Modal Kerja terhadap Usaha Kecil dan Menengah (Studi Kasus Pada Bank BRI KCP Sukun Malang). Jurnal Ilmiah. Malang: Jurusan Ilmu Ekonomi Fakultas Ekonomi dan Bisnis Universitas Brawijaya

Hasibuan, T. 2003. Pengaruh Informasi Akuntansi terhadap Keputusan Pemberian Fasilitas Kredit Modal Kerja pada Bank Bumiputera Cabang Medan. Tesis. Medan: Program Pascasarjana Universitas Sumatera Utara.

Ikit. 2015. Akuntansi Penghimpunan Dana Bank Syariah. Yogyakarta: Dee Publish.

Indriantoro, N. \& B. Supomo. 2002. Metodologi Penelitian Bisnis. Yogyakarta: BPFE.

Jacob, R., Q. Presley, H. Sabijon, \& S. Tangkuma. 2014. Analisis Kinerja Laporan Keuangan Perusahaan dan Penilaian Agunan Dalam Keputusan Pemberian Kredit Modal Kerja pada PT Bank Rakyat Indonesia (Persero) TBK Cabang Manado. Jurnal EMBA. 2 (3).

Karo-karo, S. 2011. Pengaruh Informasi Akuntansi dan Informasi Bukan Akuntansi terhadap Pengambilan Keputusan Kredit pada PT. Bank Sumut Cabang Imam Bonjol Medan. Tesis. Medan: Program Pascasarjana Universitas Sumatera Utara.

Kasmir. 2014. Manajemen Perbankan. Edisi Pertama. Jakarta: Penerbit Raja Grafindo Persada.

Kitindi, E.G., B.A.S. Magembe, \& A. Sethibe. 2007. Lending Decision Making and Financial Information: The Usefulness of Corporate Annual Reports to Lenders in Botswana. The International Journal of Applied Economics and Finance 1.

Mahrinasari. 2003. Pengelolaan Kredit pada Bank Perkreditan Rakyat di Kota Bandar lampung. Jurnal Ekonomi dan Bisnis. (3).

Matondang, A.W. 2011. Pengaruh Informasi Akuntansi dan Informasi Non Akuntansi terhadap Pengambilan Keputusan Kredit Kupedes Modal Kerja Pada PT. Bank BRI Iskandar Muda Medan. Tesis. Medan: Program Pascasarjana Universitas Sumatera Utara.

Mintarti. 1994. Pengaruh Informasi Akuntansi dalam Pengambilan Keputusan Kredit pada Perbankan di Pulau Kalimantan. Tesis. Yogyakarta: Program Pascasarjana UGM.

Niode, M.P., D.P.E. Saerang, \& V. Ilat. 2016. Analisis Penggunaan Informasi Akuntansi dan Informasi Non Akuntansi dalam Keputusan Pemberian Fasilitas Kredit Pada PT. Bank Mandiri (Persero) Tbk. Area Manado. Jurnal Riset Bisnis dan Manajemen 5(2).

Nurdiwaty, D. \& Faisol. 2017. Analisis Financing to Deposit Ratio, Debt to Equity Ratio, Return on Equity, dan Quick Ratio terhadap Pembiayaan Murabahah pada Bank Umum Syariah di Indonesia. Jurnal Akuntansi \& Ekonomi FE UN PGRI Kediri 2(2).

Obara, C.L. \& B.O. Eyo. 2004. Accounting Information and Commercial Bank Lending Decision in Nigeria: An Empirical Analysis of Selected Banks in Port Harcourt. Journal of Business Studies 2(1) Purba, M.A. 2017. Pengaruh Informasi Akuntansi dan Informasi Non Akuntansi terhadap Keputusan Pemberian Kredit dengan Pengalaman sebagai Variabel Moderating pada Bank Swasta Kota Batam. Jurnal Ilmiah Manajemen 5(2). 
Penggunaan

Rasio

Keuangan...

186
Putranto, D.S. \& E.D. Arfinto. 2014. Analisis Conjoint Faktor-Faktor yang Mempengaruhi Perilaku Bank Perkreditan Rakyat (BPR) di Kota Semarang dalam Penilaian Kredit Modal Kerja. Jurnal Studi Manajemen \& Organisasi 11(2).

Saleh, M.M.A., Z.O.E. Al Amaideh, H.M.A. Baniatta, \& A.M.S. Alrjoub 2014. The Reflection of Applying New Developed Approaches in Accounting Information System on Investment and Credit Decisions in Commercial Banks in Aqaba Special Economic Zone. Asian Journal of Finance \& Accounting 6(1).

Schneider, Arnold. 2018. Studies on the Impact of Accounting Information and Assurance on Commercial Lending Judgments. Journal of Accounting Literature 41.

Septriawan, R.M. 2010. Pengaruh Informasi Akuntansi dan Informasi Non Akuntansi terhadap Pengambilan Keputusan Kredit pada PT. Bank CIMB Niaga Tbk Cabang Medan Petisah. Tesis. Medan: Program Pascasarjana Universitas Sumatera Utara.

Sucipto, T.N. 2011. Pengaruh Informasi Akuntansi dan Informasi Non Akuntansi terhadap Keputusan Pemberian Fasilitas Kredit Modal Investasi dengan Pengalaman Sebagai Variabel Moderating Pada Bank Bukopin Cabang Medan. Tesis. Medan: Program Pascasarjana Universitas Sumatera Utara.

Sudaryono. 2005. Persepsi Analis Kredit tentang Informasi Akuntansi dan Non Akuntansi Pengaruhnya terhadap Keputusan Kredit (Studi Perbandingan antara BNI dan Mandiri Wilayah Jateng dan DIY). Tesis. Semarang: Program Pascasarjana Universitas Diponegoro.

Suroso. 2013. Pengaruh Informasi Akuntansi terhadap Pengambilan Keputusan Kredit pada PT. Bank Mandiri TBk Cabang Medan Imam Bonjol. Jurnal Akuntansi Bisnis dan Publik 4(1).

Suryaputra, A.N. 2009. Cara Efektif Menyusun dan Mengajukan Proposal Kredit. Yogyakarta: Zenith Publisher.

Tjondro, E. \& Basuki. 2012. Studi Tentang Political Tie, Pengaruhnya terhadap Keputusan Pemberian Kredit Bank di Indonesia. Jurnal Akuntansi dan Keuangan 14(2).

Trönnberg, Carl-Christian \& S. Hemlin. 2014. Lending Decision Making in Banks: A Critical Incident Study of Loan Officers. European Management Journal $32(2)$.

Ustadi. 1993. Pengaruh Informasi Akuntansi dalam Pengambilan Keputusan Kredit oleh Bank Rakyat Indonesia Kantor Wilayah Daerah Istimewa Yogyakarta. Tesis. Yogyakarta: Program Pascasarjana UGM.

Zremag, A.K. 2016. Accounting Information Systems in Making Credit Decision. International Journal of Scientific and Research Publications 6(9). 